\title{
Porous Nation: From Ireland's 'Haemorrhage' to Immigrant Inundation - A Critique of Ireland's Immigration Act, 1999
}

\author{
Jason King
}

\begin{abstract}
This paper examines the impact of metaphors of fluidity for migratory processes upon the development of public opinion in Ireland, both to trace the effects of historical Irish outmigration on perceptions of recent immigration, and to demystify rhetorical strategies that stigmatize asylum-seekers and refugees in Ireland as part of an expanding pool of illegal immigration, rather than as victims of persecution in need of international protection. The focus throughout the discussion is upon the range of different discourses underlying these metaphors of fluidity and how they become transformed over time, as well as their influence in engendering public hostility towards first emigration and then asylum-applicants and refugees coming into the country, following Ireland's transition from an 'emigrant nursery' to an immigranthost society.
\end{abstract}

\section{Résumé}

Cet article examine l'impact de la métaphore de la fluidité du processus migratoire sur le développement de l'opinion publique en Irlande. Cette analyse est produite à la fois pour retracer leseffets del'émigration historique des irlandais sur la perception qu'ils se font de la récente immigration, et pour désamorcer les

Jason King is a doctoral student in the English Department at the National University of Ireland, Maynooth, where he is writing his dissertation on the literature of emigration from Ireland to Canada during the midnineteenth century, as well as current representations of asylum-seekers and refugees coming into Ireland today. $\mathrm{He}$ is also a volunteer for the Irish Refugee Council, where he has worked both in the Council for Documentation and Research Section as well as in its Legal Research Unit. stratégies rhétoriques qui stigmatisent les demandeurs d'asile et les réfugiés en Irlande en y voyant la manifestation d'une vague montante $\mathrm{d}^{\prime}$ immigrationillégale, plutôtque d'y voir le geste de victimes de persécutions requérant une protection internationale. L'attention de la discussion porte sur l'éventail de discours distincts sous-tendant ces métaphores de fluidité, leur transformation au fil du temps, leur influence sur un engendrement de l'hostilité du public envers l'émigration historique, puis envers la venue au pays de demandeurs d'asile et de réfugiés, au fur et à mesure que l'Irlande se transforme de'pépinière à émigrants' à terre d'accueil à l'immigration.

\section{Introduction}

The most pressing reason for the speedy passage of Ireland's Immigration Bill, 1999, according to the Minister of State for Justice, Mary Wallace, was the need to protect Irish society from the "inflows of criminal elements" (Irish Times, July 2, 1999). Following the High Court judgement in the case of Laurentiu v. Ireland (22 January, 1999) that struck down the deportation provisions of the 1935 Aliens Act, and the upholding of that decision by the Irish Supreme Court (20 May, 1999), Ireland's "deportation loophole" needed to be plugged, stated Minister of Justice, Equality and Law Reform, John O'Donoghue (whotabled the Bill), in order to "prevent and discourage illegal immigration" (Irish Times, January 108; Pollock; Watt, 2930). One year earlier, Minister O'Donoghue had also expressed his vehement opposition to a proposed amnesty for the backlog of asylumseekers in Ireland, because "it would send the wrong signal in terms of ad- dressing illegal immigration flows". ${ }^{1}$ More recently, a spokesman for the Department of Justice warned that if work permits were granted to asylum-seekers, "the flood gates would be opened". ${ }^{2}$ What each of these pronouncements emphasize in common, then, is an implicit association between Irish immigration and threatening metaphors of fluidity: one that gradually elides the distinction between asylum-seekers, "illegal immigration flows", and "inflows of criminal elements" to manipulate public opinion and stigmatize those seeking asylum in Ireland through what Crepeau terms an "illegitimacy transfer" (2-3). Such pronouncements from Department of Justice officials also encapsulate sentiments that have become widespread, as not just reported but inculcated by a large cross-section of the Irish media in the past couple of years (Collins, 103108; Pollock; Watt, 29-30). As Phillip Watt observes, "the repeated assertion that there is a flood or tide of refugees and asylum-seekers coming to Ireland" has helped create an "atmosphere of fear" and intolerance towards them (29). Indeed, one should not underestimate the extent to which alarmist rhetorical strategies, negative media coverage, and hostile public-opinion not just in Ireland but throughout the Western world effectively constrain, shape and determine respective national immigration and refugee policies (Simon \& Lynch). And yet, the invocation of 'floods and tides' to describe Irish migratory processes is not limited to Ireland's recent upsurge in asylum applicants. Rather, it can be attributed to a recrudescence of metaphors of fluidity that have characterized Irish emigration for at least one hundred and fifty years, following the 'Famine tide' of 1847. My intention here is to examine the evolution and transformation of 
these metaphors of fluidity in the period between the Famine of 1847 and the Dublin Convention (1990), both to trace the effects of historical Irish outmigration on perceptions of recent immigration, and to demystify rhetorical strategies that stigmatize asylumseekers and refugees in Ireland as part of an expanding pool of illegal immigration, rather than as victims of persecution in need of international protection.

\section{Metaphors of Fluidity}

It is now commonplace to remark that the rhetoric of migration frequently represents population displacements through metaphors of fluidity. Writers employing legal, academic, and journalistic registers all tend to describe population movements as 'influxes' and 'outflows', 'immersions' and 'outpourings', 'floods', 'tides' and 'waves', with varying degrees of self-consciousness about the impact of their figurative language upon perceptions of migration. What is less commonly noted, however, are the discourses underlying these metaphors of fluidity and how they become transformed over time, that is, the extent to which these metaphors themselves are diachronically constructed, and subject to modification and periodization, rather than ahistorical, immutable, and static figures of representation. Accordingly, I want to telescope the representations of two historically disjunctive moments in patterns of Irish migration and survey the evolution and transformation of metaphors of fluidity between them. More specifically, I want to focus first on the period of the rapid expansion and institutionalization of the emigrant trade in the 1830 s and 1840 s leading up to the Famine migration from Ireland, and then I want to turn to the reverse flow of increasing asylum-seekers coming into the country in the late 1990 s, as part of the same process of discourse transformation underlying Ireland's transition from an emigrant to an immigrant host society.

The danger inherent in this type of discourse analysis, however, is that it obfuscates the grim materiality of the conditions and conflicts that give rise to population displacements and refugee movements in the first place (Rapport, 77; Said, 159-161). And yet, it can be argued that nothing has a more immediate impact on the lives of refugees in countries of first asylum and resettlement than public-opinion, their representation by the media, and the rhetorical strategies that are often employed to incite feelings of hostility and even acts of violence against them. ${ }^{3}$

\section{From Gothic to Social Darwinism}

My argument, then, is that whereas in the mid-nineteenth-century representations of Irish outmigration were usually encapsulated within a larger Gothic discourse, that depicted it through metaphors of hemorrhaging, blood-letting, and cultural anaemia for the social disruption caused by population depletion, this ultimately becomes superseded in the 1990s by an emergent discourse of Social Darwinism, rooted in the residue of natural selection, competition for limited resources, and economic determinism, that has come to represent the arrival of asylum-seekers into Ireland as a form of natural disaster. ${ }^{4}$ In other words, in the period between the Famine and the Dublin Convention (1990) Gothic Supernaturalism gradually gives way to Natural Selection in conditioning metaphors of fluidity for Irish migratory processes.

In saying this, however, I do not want to imply that there is either a simple process of supercession or a reductive dichotomy between the two. Rather, it has been suggested that both the Social Darwinist and Gothic emerge dialectically related to one another within the same nineteenth-century purview and at opposite ends within the same ideological continuum, as Enlightenment and counter-Enlightenment discourses that illustrate either the rigid social application or obverse reaction against the rise of "instrumental rationality". 5 For my purposes though, it is enough tonote that in mid-nineteenth-century Ireland the Gothic was the dominant and the Social Darwinist the recessive discourse underlying various representations of the Irish exodus, whereas the two havenow become inversely related in the public perception of asylum-seekers and refugees. At issue, in other words, is the way in which each of them gives rise to similar rhetorical strategies that stigmatize migration by construing any deviation in the national population level as a threat to the normative social order.

\section{Porous Nation}

What each of these discourses emphasize in common, however, is the fundamental passivity of the Irish nation before migratory pressures that render it prostrate and unable to regulate the population movements that traverse its borders. For whether migration is portrayed as a form of social enervation or immigrant inundation, both discourses construct Ireland as porous, vulnerable, and subject to external migratory controls. Each of these discourses thus also gives rise to fundamental anxieties not only about the liquidation of international boundaries but also, more specifically, about the self-selectivity of those migrant populations who first would exit and then enter the Irish nation. In the Famine period, for example, Irish Nationalist and Tory Unionist commentators alike opposed the outmigration of either the "industrious classes" of an independent Catholic "yeomanry" or the 'lower order of Protestants' through recourse to the same Gothic metaphors of 'draining lifeblood', splintered 'bone and sinew', and social haemorrhage. These, in turn, became absorbed into a critique of the Union between Great Britain and Ireland (1800) as either in need of Repeal or imperial retrenchment for purposes of population retention. More recent constructions of refugees 'flooding into Ireland,' on the other hand, shift the

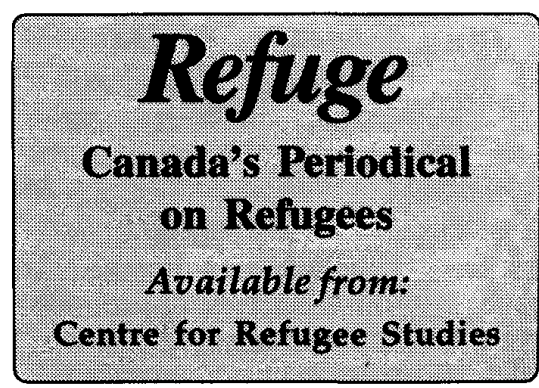


discourse to apprehensions of strained resources that are figured in terms of an imminent natural disaster. It is partially this rhetorical strategy, for example, thatenables the Irish Department of Justice, Equality, and Law Reform to circumvent existing statutory protections for asylum-seekers enshrined in the Irish Refugee Act (1996) with minimal opposition, because of the ostensible need for ad hoc, contingent and discretionary procedures as measures of 'containment' for the 'refugee crisis' that then becomenormative as Ireland's refugee reception policy (Byrne, 107117).

Yet to whatever extent Ireland suffers from a'refugee crisis' it is clearly a crisis of representation. For whether it be in the discursive fields of legal, media, or parliamentary representation, the image of the refugee has become over-determined and conflated with other categories of migrant - so that traditional conceptions of political displacement and enforced migration, whereby refugees come to Ireland because of a well founded fear of persecution abroad, are increasingly destabilized by perceptions of asylum-seekers as economic agents, who misrepresent their displacement in terms of human rights violations to cloak their exploitation of Ireland's supposedly generous social and economic entitlements. What each of these Gothic and Social Darwinist discourses lead to therefore is a concept of migratory self-selection in which, to put it bluntly, 'back then', at the time of the Famine, it was always the best who left, whereas now in the 1990s it is always the worst (economic aliens, parasites, spongers) who would come to Ireland.

\section{Ireland's 'Haemorrhage'}

Unlike today, in the mid-nineteenth century, both Irish Nationalist and Tory Unionist commentators feared population depletion rather than immigrant inundation. They each employed a Gothic discourse to object not just to the phenomenon of emigration in general but specifically the departure of their respective population cohorts, and the evacuation of their social bases of sup- port. Each group envisioned Ireland as an organic entity whose steady loss of people they imagined as a form of degenerative illness or social haemorrhaging.

Space restrictions permit only a truncated discussion here of Irish Nationalist and Tory Unionist rhetorical strategies that invoked the same Gothic conventions of blood-letting, haemorrhaging, and collective anaemia to oppose emigration as representing a diminution of their respective political interests; but suffice it to say that writers from both traditions frequently turned to the Gothic to depict the social disruption caused by population depletion. Each would thus equate the emigration of their respective cohorts with a metaphorical loss of blood to foreground its abnormality, its aberrant rather than routine occurrence within the imperial circulation of peoples and commerce. Accordingly, whereas writers in the cultural nationalist publication The Nation frequently employed Gothic metaphors of fluidity to lament the loss of an independent Catholic yeomanry ostensibly at the heart of the nationalist project, for the Tory Unionist Dublin University Magazine it was the migration of the lower class of Protestants that was figuratively seen, as a form of hemorrhaging, to curtail the life span of both the Irish Union and the British Empire. ${ }^{6}$ In both cases, though, the Irish nation or the Irish Union was envisioned as equally passive and helpless before the very population losses that would inevitably hasten its own demise.

\section{Immigrant Inundation}

If we turn now to more recent perceptions of refugees 'flooding into Ireland', the Irish nation is similarly envisioned as passive, porous, and subject to external migratory controls, albeit for very different reasons. For whereas in the mid-nineteenth century, metaphors for migration were entirely constructed in terms of national depletion, fluid seepage, and loss, the reverse flow of increasing asylum-seekers coming into Ireland tends to be imagined as a form of immigrant inundation, a population stream that threatens to drown the nation in place of its traditional drainage. Against the backdrop of Ireland's transition from an emigrant to an immigrant host society, an emergent discourse of Social Darwinism has gradually superseded its Gothic predecessor, to reconstruct Irish migratory processes in terms of 'floods', 'tides', and as a variant of natural disaster. Under this rubric of Social Darwinism, immigrants to Ireland, mainly asylum-seekers and refugees, are associated not with human rights violations buteconomic survival strategies, competition for limited resources, and outright opportunism, as the 'spillover' of other nations' poverty that puts Ireland's capacity to sustain its own populace under strain. Accordingly, in the period between the Famine and the Dublin Convention, 'haemorrhaging' has gradually given way to 'sponging', 'vampirism' to 'parasitism', 'blood-lines' to the 'dole-queue', and much more recently, the 'brain drain' to a 'traffickers' haven', as dominant images for would-be migrants in the popular imagination and media coverage of population displacement. A series of paradoxically mixed metaphors emerges here to stigmatize migratory self-selection as a degenerative social influence across a range of different discourses, while implying that the nation's incapacity to regulate its population level has changed little over time.

Evidence of a Social Darwinist mindset is more than apparent in recent press coverage and Oireachtais (parliamentary) debates about asylum-seekers and refugees. As Andy Pollock alleges, "sensational headlines, misleading statistics, unsourced claims, and often plain demonising of asylum-seekers" (15) have frequently marked this press coverage, especially that of Ireland's Independent Newspaper Group. For example, calamitous imagery equating recent immigration with a form of natural disaster has been the recurrent theme in headlines such as " 5000 Refugees flooding into Ireland" (Irish Independent, May 29, 1997) and "Demand to curb... tide on refugees" (Sunday World, May 20,1997). The ensuing apprehension of strained resources in- 
forms further headlines like "Services face overload as refugee flood continues" (Sunday Business Post, May 18, 1997), "Refugee Flood to spark home crisis" (Irish Independent, June 12, 1997), "Asylum seekers and homeless vie for shelter" (Irish Times, May 9, 1997), and "Crackdown on 2000 sponger refugees" (Irish Independent, June 7, 1997).

The dominant themes that emerge here are those of a resource burden and burgeoning criminality, both of which come together under the notional banner 'refugee crime-wave' that implicitly associates asylum-seekers with the need for greater law enforcement and cost reduction together under a single heading. Even more inflammatory are alarmist headlines that implicitly link the two to augur social extinction, such as "Refugee rapist on the rampage" (The Star, June 13,1997) and "Refugees flooding maternity hospitals (Evening Herald, June 6, 1997)," that incite fear of cultural and racial contamination in the very act of inhibiting the host population's capacity to reproduce itself. What entails from such calamitous imagery, then, is a growing sense of necessity for extraordinary measures and the use of discretionary powers to 'contain' the refugee crisis. In times of crisis and natural disaster, in other words, the nation must resort to contingency measures it normally would not countenance to ensure its self-preservation. Calamity, contingency, the threat of extinction, the struggle for reproduction, and instinctive self-preservation: all of these, of course, are variants of a principle of NaturalSelection within a larger Social Darwinist discourse.

The influence of Social Darwinism is less evident but also still perceptible in several recent Irish Oireachtais debates on the subject of immigration and refugee policy. "On my appointment as Minister for Justice, Equality, and Law Reform" in June 1997, stated John O'Donoghue last year, "one of the first issues to be brought to my attention was the surge in the number of asylum seekers which had been experienced" after passage of the Refugee Act (1996). ${ }^{7}$ "The extent of the surge experienced"- from 424 applicants in 1995 to almost 4000 last year-was such "that the structures provided for in the Act would have been totally overwhelmed from day one, had we gone ahead with its implementation". Therefore, it has only been selectively implemented in tandem with departmental directives that "seek to regulate immigration flows" and prevent them from taking "place in a totally haphazard and unregulated manner".

The Minister's comments are framed then in familiar terms of disaster prevention, cost reduction, and the need for national self-preservation, by erecting discretionary barriers where "there is no legislative framework in place to [restrict] the further influx of migrants". In practice, this has meant adopting a restrictive definition of the Refugee Convention; implementing strictly the removal proceedings of the Refugee Act, including judicious application of the Dublin Convention (Irish Times, May 27,1999), to circumvent the Act's transparency, multi-stage determination procedure, and measures of procedural fairness; drafting guidelines to root out "Manifestly Unfounded" applications; ${ }^{8}$ occasional exclusions of members of visible minorities at border checkpoints (Irish Times, April 24, 1999); and delaying the appointment of independent appeals officers, although this has recently been rectified and is reflected in substantially improved recognition rates (Irish Times, June 3, 1999). "Less amenable to calamitous imagery," on the other hand, notes Byrne, is the mundane reality of "administrative paralysis" that remains the underlying cause of the "logjam" and the "refugee crisis" (110).

Behind these calamitous metaphors of fluidity, however, also lies the more stark, socio-economic parlance of limited resources, demographic pressure, potentiallabour strife, and strained law enforcement, as a result of "illegal immigration flows". For "the magnitude of the influx" has generated a number of associated costs, Minister O'Donoghue continues, including "social welfare, housing, education, health care, em- ployment, etc.," all of which "must also bebornein mind" when devising immigration and refugee policy. Moreover, external, global factors such as acute poverty, underdevelopment, evermore accessible and extensive transportation links, and people trafficking have all rendered Ireland particularly vulnerable to an increasing "number of persons who seek asylum as refugees when it is economic pressures which are motivating [them] rather than political persecution". In effect, it might be argued that Ireland currently perceives itself to be experiencing the same economically induced, sharp increase in asylum applicants and permutation of the "refugee crisis" that affected many Western European and North American nations in the mid-1980s (Hawkins, 386-389; Kelley \& Treblicock, 382-440;Zolberget al,278-282), but has reacted by suspending its own Refugee Act as far too cumbersome to handle the increased caseload without ever even putting that legislation fully to the test. It is this prevailing sense of crisis that has informed recent discussion of Ireland's Immigration Bill, 1999.

\section{Immigration or Deportation Bill?}

In a rare moment of levity during the discussion of Ireland's Immigration Bill, Minister O'Donoghue began to lecture the House on the etymology of the term "aliens":

It owes its origin - he explained - to the Latin noun and adjective alienus, which simply conveys a quality of "elseness". Nowadays it is more likely to conjure up images of outer space than of people from other countries. I am happier to see its use discontinued [and replaced by the term "non-national"...] That said, if there is ever an invasion from outer space, I have no doubt-

Mr Howlin: The Minister will deport them.

Mr O'Donoghue: —-the aliens legislation will be revived. ${ }^{9}$

We will put aside the question of whether the outlandish term "aliens" 
suggests "invaders from outer space" rather than "people from other countries", and to what extent the rise of science fiction as a genre is ultimately bound up with Cold War politics and fear of the "enemy within". More pertinent here is the fact that Minister O'Donoghue's comments obfuscate the distinction between immigration into Ireland in general - whether it be the movement of "aliens" or "non-nationals" - and the more specific intent and much narrower scope of the legislation: to deport failed asylum applicants and exclude "undesirable non-nationals" from entering the country. ${ }^{10}$ The Minister's seemingly liberal adoption of the term "non-national", in other words, conceals the function of the legislation and, according to opposition Deputy De Rossa, his failure to produce any sort of "policy document which outlines government thinking on how immigration will impact upon [Irish] society". ${ }^{11}$ As opposition deputy Michael Higgins also objected in the House: "it is a great tragedy that we are considering legislation that is effectively the housekeeping of deportation rather than discussing the principles of a policy on refugees or migrants".

\section{No Queues to Jump}

Throughout his term of office, Minister O'Donoghue has insisted upon the need to distinguish rigorously between "genuine refugees" and "illegal immigrants."12 He has also frequently reiterated that "the reality, in line with international experience, is that at most about 10 percent of applicants will... be found to be refugees"13 - a statement that quickly became a self-fulfilling prophecy with respect to recognition rates (Irish Times, March 23, 1999), yet remains patently false in light of Canadian experience (Kelley \& Treblicock, 427), and is belied even by the Irish Government's own recently instituted independent appeals procedures (Irish Times, June 3, 1999). Both statements must therefore be considered disingenuous, given that Ireland has no immigration policy apart from asylum procedures for voluntary immigrants to avail of, and therefore no legal means of entry to alleviate pressure from irregular population movements. Although the UNHCR suggests that "it is not healthy for the asylum system of any country that there should only be one channel (asylum-seeking) whereby immigrants from outside the EU can get in," Ireland has yet to expand its means of entry, despite repeated calls for some form of regularized immigration (Irish Times, April 30, 1999). “Because the state restricts immigration to the asylum route," adds Pauline Faughnan of the Social Science Research Centre at University College Dublin, that route becomes "abused" (Irish Times, April 30, 1999). Thus, unlike in other western nations, where fraudulent asylum applicants are condemned as "queue jumpers" seeking to circumvent lengthy immigration procedures, in Ireland, in effect, there are no queues to jump.

What follows is that those seeking to immigrate voluntarily to Ireland are caught within a categorical squeeze, between making a spurious asylum application on the one hand, and outright exclusion on the other. "Ab initio, on arrival in the land," states Minister O'Donoghue, "an individual is either anillegal immigrant or a refugee". ${ }^{14}$ The Minister is thus in no position to offer the guarantee, at the behest of UNHCR, that Ireland's "immigration and asylum policies do not get confused, ${ }^{\prime 15}$ because they are, in effect, one and the same. Nor is he in any position to reassure UNHCR that he seeks to "avoid the public perception that equates refugees with illegal aliens, and weakens the awareness of those in need of protection,"16 because he himself has frequently and publicly cast doubt upon the validity of the vast majority of asylum applications in Ireland. While it is obvious that all states have to take measures to distinguish between genuine asylum applicants and illegal immigrants as one plank of refugee protection and as a function of sovereignty, it would also seem incumbent upon states like Ireland not to overburden their asylum procedures by restricting access into the country from all other channels.
The conclusion that should be drawn here is that some form of elective immigration policy is not merely auxiliary but an essential corollary of refugee protection, and that it is detrimental to the well-being and public perception of asylum applicants when their procedural means of entry is also, by law, the sole conduit of legal (and hence illegal) immigration (also see Habermas for a similar analysis of the politics of asylum in Germany, 141-148).

Finally, it needs to be said that no European country is more vulnerable to the pressure from extra-legal remedies for failed asylum applicants and economic migrants than Ireland. Ireland's history of emigration extends not just from the Famine and Pre-Famine periods but up until as late as the mid-1980s, when officials from the Irish Government vigorously lobbied the United States administration to permit undocumented "Irish illegals" in America to remain (Corcoran). Minister O'Donoghue's remark that "Ireland has traditionally been regarded as a country of emigration rather than immigration" 17 is in many respects a prescriptive instead of a descriptive statement, and it can be interpreted to provide a rationale for shifting the burden of accepting asylum-seekers away from Ireland to other countries of resettlement; but Ireland's history of emigration has also been mobilized very effectively to create feelings of empathy for immigrants and for purposes of advocacy, both in the Oireachtais and in society at large. Ultimately, by framing Ireland's immigration legislation strictly through the lens of refugee determination, Ireland's Justice Department obfuscates not just the more vexing issues surrounding recent Irish immigration, such as, first of all, the nation's glaring lack of policy, determination of absorptive capacity, or statement of a notional desirable rate of increase in lieu of its so-called crisis proportion; but also, secondly, it fails to acknowledge Ireland's profound ethical and historical obligations to permit at least a portion of its economic aliens and non-coerced migrants humanitarian leave to remain, if for no other reason, then because of its robust economic 
expansion that increasingly implicates Ireland in a growing network of socioeconomic disparities world-wide. It is, after all, very easy for Ireland to insist it is being flooded with immigrants, in the absence of any stipulated policy, normative criterion, or water marker by which to measure its population overflow.

\section{Conclusion}

Therefore, in a spirit of intervention, I would like to suggest that the point here is not to refute but to refigure these metaphors of fluidity, in a manner more sympathetic to the plight of Ireland's economic aliens, asylum-seekers, and refugees. In Metaphors We Live By (1980), Lakoff and Johnson state that "metaphors may create realities for us, especially social realities" (156). "In most cases," they add, "what is at issue is not the truth or falsity of a metaphor but the perceptions and inferences that follow from it and the actions that are sanctioned by it" (158). "We... pay the cost of this bad [press] coverage," confirms refugee Khalid Ibrahim of ARASI, 18 for "it leads to attacks from people who don't know the reality" (Irish Times, February 25, 1998). Metaphors of fluidity, like that of refugees flooding into Ireland, thus generate a network of social entailments that incur hostility towards would-be migrants, bring pressure to bear on governmental agencies to control and contain the perceived immigration influx, and even give rise to a backlash against visible minorities long settled and established in the country, all because of often misleading presumptions about their economic impact upon Irish society.

And yet, most demographic pronouncements about population excess in twentieth-century Ireland, notes J.J. Lee, contain a "number of silent assumptions, untested empirically," that appear untenable by any comparative criterion (381). By the same token, Ireland's refugee crisis involves such a small order of magnitude on a comparative European or global basis, that it seems more the result of bureaucratic inertia and discretionary policy than any failure in the nation's absorptive capacity to take in would-be migrants. What follows is that Ireland suffers from a form of metaphorical rather than population excess.

We need therefore to reconfigure established metaphors for Irish migration, perhaps even viewing recent immigrants as a badly needed transfusion of people and labour supply to help fuel Ireland's continuing robust economic growth. The Canadian journalist Victor Malarek's prognosis of the so-called Canadian 'refugee-crisis' in the late 1980 s might have equal bearing on Ireland today:

although the number of people claiming refugee status has been growing, -Malarek writes - compared with the thousands accepted by [other] European nations, the [Irish] wave is more like a cresting stream; compared with front-line Third World countries, with millions of refugees confined to camps, it is [but] a trickle.(129-130)

The reconfiguration here of more established metaphors of fluidity, replacing 'floods and tides' with 'streams and trickles', contests the social reality and economic anxieties they construct. It enables a new, comparatively adjusted perspective on Ireland's and other nations' immigrant reception, hopefully one that is more sympathetic and less antagonistic towards asylum-seekers and refugees.

\section{References}

Byrne, Rosemary. 1997. "On the Sliding Scales of Justice: The Status of Asylum Seekers and Refugees in Ireland," Developments in Discrimination Law in Ireland and Europe, eds. Rosemary Byrne \& William Duncan. Dublin: I.C.E.L., p.107-117.

Collins, Adrienne. 1997. "Is Ireland Meeting its International Obligation towards Refugees?", Trocaire Development Review. Dublin, p.93-114.

Corcoran, Mary. 1993. Irish Illegals: Transients Between Two Societies Westport CT: Greenwood Press.

Crepeau, Francois. 1996. "International Cooperation on Interdiction of Asylum Seekers: A Global Perspective" (Ottawa: Canadian Council for Refugees Interdiction Workshop).

Habermas, Jürgen. 1994. "Struggles for Recognition in the Democratic Constitutional State," in Charles Taylor,
Multiculturalism: Examining the Politics of Recognition, ed. Amy Gutmann. Princeton, New Jersey: Princeton University Press.

Hawkins, Freda. 1988. Canada and Immigration: Public Policy and Public Concern, $2^{\text {nd }}$ ed., Montreal: McGill-Queen's University Press.

Horkheimer, Max, \& Theodor Adorno. 1990. Dialectic of Enlightenment (1944). New York:Continuum.

Kelley, Ninette \& Michael Treblicock. 1998. The Making of the Mosaic: A History of Canadian Immigration Policy. Toronto: University of Toronto Press.

Lakoff, George, \& Mark Johnson. 1980. Metaphors We Live By. Chicago \& London: University of Chicago Press.

Lee, J.J. 1989. Ireland, 1912-1925: Politics and Society. Cambridge: Cambridge University Press.

Malarek, Victor. 1987. Haven's Gate: Canada's Immigration Fiasco. Toronto: Macmillan.

Pick, Daniel. 1989. Faces of Degeneration: A European Disorder, c. 1848 - c. 1918. Cambridge University Press.

Pollock, Andy. 1998. "Address to the Clearun Media Conference," 21 February, 1998, extracted in The Irish Times, February 23, 1998.

Rapport, N. 1997. Transcendent Individuals. New York: Routledge.

Said, Edward. 1984. "Reflections on Exile," Granta 13, p.158-172.

Simon, Rita J. \& James P. Lynch. 1999. "A Comparative Assessment of Public Opinion Toward Immigrants and Immigration Policies," International Migration Review 33, no. 2, p.455-467.

Watt, Philip. 1998. "Reporting on Refugees," Focus 57/58, p.29-30.

Zolberg, Aristide, Astri Suhrke, \& Sergio Aguao. 1989. Escape from Violence: Conflict and the Refugee Crisis in the Developing World. Oxford University Press, 1989.

\section{Notes}

1. Dáil Debates Official Report-10-3-98. PRIVATE MEMBERS' BUSINESS. Asylum Seekers (Regularisation of Status) (No. 2) Bill, 1998: Second Stage. (http:// www.irlgov.ie/oireachtas/frame.htm).

2. Oireachtas Committees Public Accounts 20 May 1999Page 1.(http:/ /www.irlgov.ie/ oireachtas/frame.htm). However, it should be noted that as of July 27, 1999, asylum-seekers who have been in the State for more than twelve months will be granted the right to work, pending the determination of their status (Irish Times, July 28, 1999). 
3. For reports of incidents of violence and institutional racism suffered by asylumseekersinIreland, see theIrish Times July 7, 1998; November 12, 1998; February 1, 1999; March 2, 1999; April 24, 1999; April 27, 1999).

4. For further consideration of Social Darwinian theory in the context of national and international conflict, population displacement, and conflict resolution, see Otunnu, Ogenga 1997. "Conflict and Conflict Resolution," Refuge 16, no. 6, p.1-5.

5. See Daniel Pick, Faces of Degeneration: A European Disorder, c. 1848 - c. 1918. 1989. Cambridge: Cambridge University Press, p.155-175. For a full length critique of instrumental rationality in the western philosophical tradition, see Horkheimer, Max, \& Theodor Adorno. 1990. Dialectic of Enlightenment (1944). New York: Continuum.

6. For two definitive examples of Irish $\mathrm{Na}$ tionalist and Tory Unionist publications that invoke Gothic conventions of haemorrhaging to oppose the emigration of either affluent Roman Catholics or lowerclass Protestants, see William Carleton. 1979. The Emigrants of Ahadarra (1848). repr. New York \& London: General Publishing, and anon. 1833. "On the Emigration of Protestants," Dublin University Magazine 1, p.471-483. Moreover, for insightful discussions of Gothic conventions in nationalist and Unionist writing of the Famine period, see Sean Ryder. 1996. "Reading Lessons: Famine and the Nation, 1845-1849," in Fearful Realities: New Perspectives on the Famine, eds. Chris Morash \& Richard Hayes. Dublin: Irish Academic press, p.151-163; Jim Mac Laughlin (ed). 1997. "Emigration and the Construction of Nationalist Hegemony in Ireland: The Historical Background to 'New Wave' Irish Emigration", Location and Dislocation in Contemporary Irish Society: Emigration and Irish Identities. Cork: Cork University Press, p.12-25; and Wayne Hall. 1999. "A Tory Periodical in a Time of Famine: The Dublin University Magazine, 1845-1850". The GreatFamine and the Irish Diaspora in America. Ed. Arthur Gribben. Amherst: University of Massachusetts Press.

7. Dáil Debates Official Report -10-3-98. PRIVATE MEMBERS' BUSINESS. Asylum Seekers (Regularisation of Status) (No. 2) Bill, 1998: Second Stage. (http:/ / www.irlgov.ie/oireachtas / frame.htm).

8. ADJOURNMENT DEBATE RefugeeLegislation 12-10-97. (http://www. irlgov.ie/oireachtas/frame.htm).
9. Immigration Bill, 1999: Order for Second Stage. (http://www.irlgov.ie.80/debates-99/9feb99/sect5.htm).

10. Committee on Justice, Equality \& Law Reform Section 1 99/06/29.

11. Immigration Bill, 1999: Second Stage (Resumed). (http://www.irlgov.ie.80/debates-99/9feb $99 /$ sect5.htm).

12. See, for example, Asylum Seekers (Regularisation of Status)(No.2) Bill, 1998:Second Stage \& Second Stage (resumed); Immigration Bill, 1999: Order for Second Stage; Oireachtas Committees Public Accounts 20 May 1999 Page 1; Committee on Justice, Equality \& Law Reform Section299/06/03; Irish Times(March23, 1999).

13. Asylum Seekers (Regularisation of Status) (No. 2) Bill, 1998: Second Stage. Also see,
Oireachtas Committees Public Accounts 20 May 1999 p.1.

14. Committee on Justice, Equality \& Law Reform Section 2 99/06/03.

15. Statement by Mrs. Sadako Ogata, United High Commissioner of Refugees on the occasion of the Inter-Governmental Consultations on Asylum, Refugee, and Migration Policies in Europe, North America, and Australia. The Hague, 17-18 November 1994 (ctd. in Interdicting Refugees. Canadian Council for Refugees: May 1998, p.21).

16. Ibid.

17. Asylum Seekers (Regularisation of Status) (No. 2) Bill, 1998: Second Stage

18. Association of Refugees and AsylumSeekers in Ireland. $\square$

\section{Background Information on the Centre for Refugee Studies}

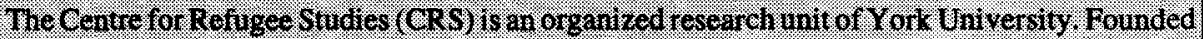

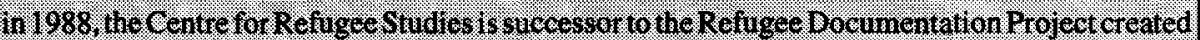
in 1981 for the conservation and andi ys s s of research doctinents and data collected by Operation

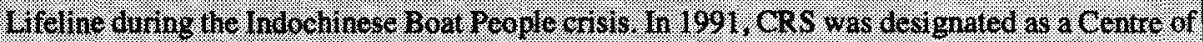
Excellence by the Canadian International De-velopment Agency (CMA)

The Centre for Retigee Studies fosters IIterdisciplinary and collaborative research in all of its

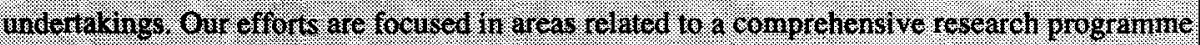
expanding from theoretical o instudional research on the aforementoned areas of study In

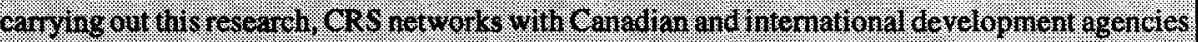
and heademic insthiles. CRS hutes schoiars fron abroad to share in he researeh. Canadian and

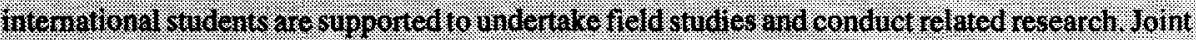

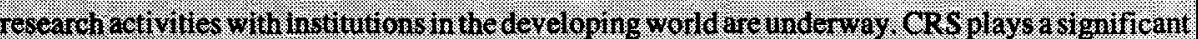
fole In an adv sory capacity with Canadian govermment and ol her agencies.

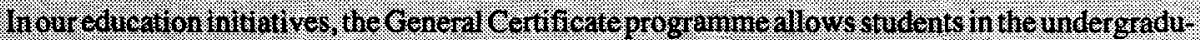

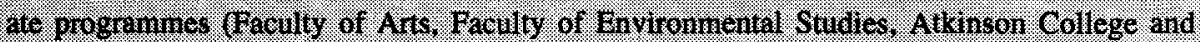

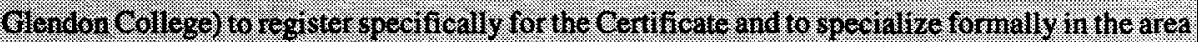

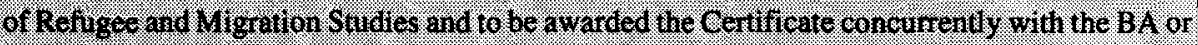

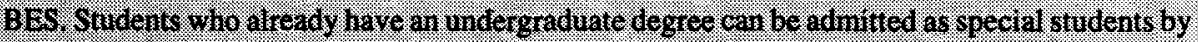

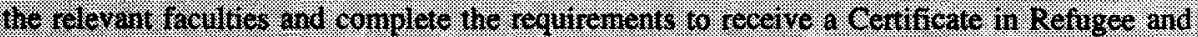

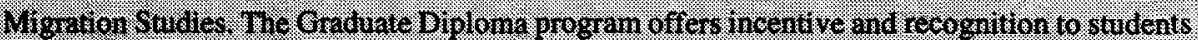

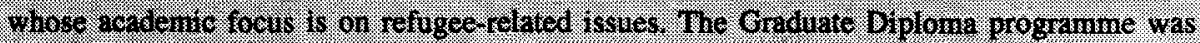

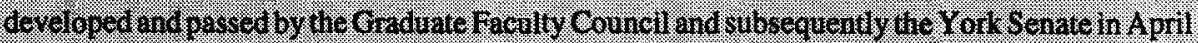

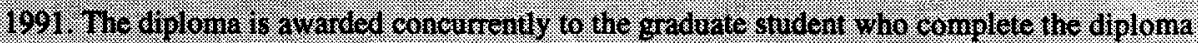
requiremenu and hie degree requirenends

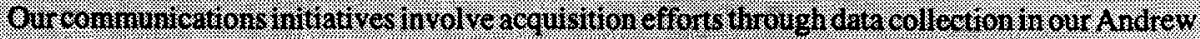

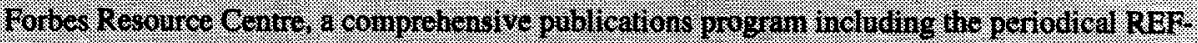

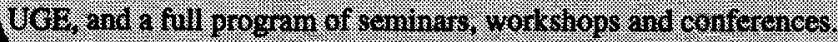

